Jan Ziótek

\title{
Towarzystwo Dobroczynności Dam Polskich
}

Od pierwszych chwil, kiedy znaleźli się na obcej ziemi, powstała konieczność pomagania najbiedniejszym. Tym, którzy nie mieli ze sobą pieniędzy i innych środków do życia, nie znali języka i nie mogli podjąć pracy. Pierwsze organizacje emigracyjne, jakie powstały o charakterze politycznym podejmowały ten problem i starały się u rządów francuskiego i brytyjskiego o pomoc materialną i finansową. Pomocy takiej rządy krajów osiedlenia udzieliły. Nie była to jednak pomoc w pełni wystarczająca. Należało więc poszukiwać dodatkowe środki na wspomaganie najbiedniejszych. Powstały zatem obok towarzystw i organizacji politycznych stowarzyszenia charytatywno-pomocowe. Jedno z nich, wielce zasłużone dla wychodźstwa polskiego w XIX wieku to: Towarzystwo Dobroczynności Dam Polskich, prawdopodobnie poprzedzone przez Komisję Funduszów Emigracyjnych - opartych na zasadzie dobrowolnego opodatkowania - powstało 12 marca 1834 roku. Oba te Towarzystwa istniały przez jakiś czas obok siebie. Później Komisja Funduszów znika, a Towarzystwo intensyfikuje swoją działalność. Pierwszy statut Towarzystwa nowi tytuł: „Projekt Ustawy Towarzystwa Pomocy dla Nieszczęśliwych Polaków na Emigracji”, opracowany przez Klementynę z Tańskich Hoffmanową i został przedstawiony przez księżnę Annę Czartoryską na posiedzeniu założycielskim i przyjęty w dniu 12 marca 1934 roku1. Wybrano wtedy skład zarządu, do którego weszły: księżna Czartoryska jako prezydująca i Hoffmanowa jako sekretarka. Pełnego składu zarządu pierwszego nie znamy. Wiadomo natomiast, że drugim sekretarzem został Hipolit Błotnicki - związany przez całe życie z domem Czartoryskich.

Artykuł pierwszy Ustawy przyjętej na tym posiedzeniu określał cel Towarzystwa, do którego należało: ,niesienie chorym pomocy, opieka nad wdowami i sierotami, zaopatrywanie w niezbędne potrzeby tych zwłaszcza, którzy od rządu zasiłku nie posiadają, staranie się dla będących w niedostatku o środki zarobku i dawanie zapomogi na rozpoczęcie rzemiosła lub innego sposobu na życie. Artykuł drugi mówi o tym, że Towarzystwo składać się będzie z sióstr, opiekunek, dystrybutorów

\footnotetext{
${ }^{1}$ Hoffmanowa była współzałożycielką Związku Patriotycznego Dam Polskich w Warszawie po wybuchu powstania listopadowego, przekształconego później w Związek Dobroczynności Warszawianek. Zob. „Pamiętnik Emigracji” 1832-1833, cz. II, s. 1.
} 
i urzędników. Następny artykuł mówi o tym, że siostrami są damy Polskie podpisujące akt założenia Towarzystwa". Na pierwszej liście znalazły się następujące nazwiska: księżna Ogińska, hrabina Platerowa, panie: Rautenstrauch, Wołowska, Łuszczewska i Małachowska. Wyżej wymienione panie tworzyły pierwszy skład Towarzystwa, którego jak wyżej zostało powiedziane, przewodniczącą była księżna Anna Czartoryska, a sekretarką Klementyna z Tańskich Hoffmanowa. na liście opiekunek obok Polek przebywających w Paryżu figurują nazwiska znakomitych Francuzek i Angielek. Jednak trzon organizacji stanowiły Damy Polskie, które nazywały siebie siostrami. Prawdopodobnie dlatego, że ich działalność emocjonalnie zbliżała je do siebie. Ponadto słowo siostra wzbudzało zaufanie darczyńców i zmniejszał się dystans między Damami Polskimi, a potrzebującymi wsparcia emigrantami. Chciały też podkreślić, że są „,siostrami”, osobami bliskimi tych, co znaleźli się w trudnej sytuacji, wykazując przy tym całkowitą apolityczność, bezinteresowność i bezstronność w udzielaniu pomocy.

Jak wynika z przeprowadzonych badań i analiz dostępnych źródeł grono Dam Polskich nie było liczne. Na przestrzeni lat 1834-1864 pracowały zaledwie 22 osoby $^{2}$, które w różnych latach działały w Towarzystwie. Jednorazowo na Liście imiennej nie było więcej jak 6 do 9 pań. Było to grono elitarne wywodzące się z zamożnej emigracji. Trzeba też zauważyć, że część działaczek chciała pozostawać anonimowo i nie zgadzała się na ujawnienie nazwisk. Wiemy też, że panie mieszkające poza Paryżem współpracowały z Towarzystwem jako korespondentki. Zadaniem ich było zbieranie pieniędzy i fantów przeznaczonych do sprzedaży na tzw. Bazarach Polskich organizowanych w Paryżu oraz wyszukiwanie w najbliższym otoczeniu osób potrzebujących pomocy ${ }^{3}$. Środki zgromadzone przez korespondentów były rozdzielane potrzebującym na miejscu, jak to robiła pani Nakwaska działająca w Szwajca$\mathrm{rii}^{4}$. Zgromadzone środki pieniężne rozdzielała $\mathrm{w}$ imieniu Towarzystwa między potrzebujących. Działalność respondentek poszerzała zakres wpływów Towarzystwa poza Paryż, a nawet granice Francji.

Księżna Anna Czartoryska umiała pozyskiwać sobie do współpracy cudzoziemców. Pomocą w tym względzie były szerokie znajomości, jakie posiadała rodzina Czartoryskich $\mathrm{w}$ domach arystokracji francuskiej i angielskiej. Zaraz po przybycie do paryża księżna spotkała przyjazne sobie księstwo de Beauveau i margrabiego d'Oraison z żoną. Ostatni był adiutantem marszałka Soulta zaprzyjaźnionego z ojcem księcia Adama Jerzego. Ponadto od samego początku działalność charytatywna Dam Polskich była znana na dworze francuskim. Popierały Czartoryską w jej działalności królowa Amelia - żona Ludwika Filipa i księżna Adelajda - jego siostra. Obie żywo interesowały się pracami Towarzystwa i jednocześnie same przyczyniały

\footnotetext{
${ }^{2}$ Biblioteka Czartoryskich w Krakowie (dalej: BCzwK), ew. 1120. A Czartoryska - papiery osobiste. Listy imienne opiekunek z lat 1836 i 1861.

${ }^{3}$ Generałowej Benigny Małachowskiej, Pamiętniki (1831-1870). „Przewodnik Naukowy i Literacki”, dodatek do „Gazety Lwowskiej”, t. 45, 1919.

${ }^{4}$ „Kronika Emigracji Polskiej”, t. 6, 1837, s. 137.
} 
się do powiększania jego dochodów swoją ofiarnością ${ }^{5}$ Z innych pań, oddanych pracy charytatywnej na rzecz emigrantów polskich, należy wymienić: księżnę Ney, panią de Lamartine, księżnę de Devonshire, księżnę Belgiojoso i panią Thayer. Panie te nadawały w tym czasie ton życiu towarzyskiemu Paryża i Londynu, co nie było bez znaczenia w popularyzowaniu działalności Towarzystwa ${ }^{6}$. W Londynie do tamtejszego Oddziału Towarzystwa należały między innymi: markiza de Lansdowne, pani Benumont i lady Dudley Stuart. Szczególnie dużą rolę w Towarzystwie odgrywała lady Stuart - Krystyna Egipte Bonaparte, córka Lucjana, brata Napoleona I - żywo interesowała się losami Polaków i cały czas współpracowała z damami Polskimi w Paryżu. Wyżej wymienione panie ni były jedynymi współpracownicami Towarzystwa, te były znane z rozreklamowanych sposobów zdobywania pieniędzy, między innymi przez organizowanie dorocznych Bazarów Polskich, bali, koncertów i kwest ${ }^{7}$. Dla przykładu podam, że w roku 1837 na liście opiekunek znajdowało się 29 nazwisk Francuzek i Angielek, a w roku 1861 aż 52 obce arystokratki współpracowały z Towarzystwem ${ }^{8}$. Uwzględniając zmiany pokoleniowe przyznać musimy dużą popularność i dynamizm działania Dam Polskich. W sumie w okresie 30 lat istnienia Towarzystwa opiekunami było 91 arystokratek cudzoziemskiego pochodzenia. Ponadto 147 Francuzek w różnych latach pomagało w organizowaniu Bazarów Polskich. Tyle nazwisk zdołano ustalić na podstawie dostępnych nam źródeł. Ponadto jest w Paryżu w Bibliotece Polskiej spora ilość nieuporządkowanych papierów tego Towarzystwa, które mogłyby zweryfikować podane tu informacje.

Niezwykle ważną rolę w Towarzystwie spełniali dystrybutorzy. Tak nazywały się osoby rozprowadzające środki pomocy w naturze i pieniądzach oraz spełniały różne funkcje administracyjne. Byli to przeważnie panowie. Do grona pierwszych dystrybutorów należało pięciu panów: Karol Marcinkowski - lekarz, powrócił do kraju w 1834 roku, andrzej Plichta - publicysta i prawnik, Piotr Ludomir Łagowski - pułkownik, czynny w licznych towarzystwach emigracyjnych, Franciszek Grzymała - publicysta, poeta, czynny w życiu emigracyjnym oraz Leonard Wolicki - kapitan. Brali oni aktywny udział we wszystkich przedsięwzięciach mających na celu gromadzenie pieniędzy, jak również rozdzielanie ich potrzebującym. Zainteresowanie panów działalnością charytatywną szybko się zwiększało i w roku 1836 na liście dystrybutorów było już 40 osób ${ }^{9}$. Wśród nich: Stanisław Barzykowski, Aleksander Jełowicki, Stanisław Małachowski, Karol Hoffman, Ignacy Domejko, Feliks Bystrzonowski, Narcyz Olizar, Ludwik Plater, Bonawentura Niemojewski i karol Orpiszewski. W wiekszości osoby te były znane w środowiskach emigracyj-

${ }^{5}$ Tamże, t. 5, 1836-1837, s. 168 i t. 4, 1836, s. 28; N. Kicka, Pamiętniki, oprac. J. Dutkiewicz, Warszawa 1972, s. 487.

${ }^{6}$ A. Lewak, Czasy Wielkiej Emigracji, w: Polska, jej dzieje i kultura od czasów najdawniejszych do chwili obecnej, red. S. Lam, t. 3, Warszawa 1930, s. 193-233.

${ }^{7}$ BCzwK, ew. 1528b. Towarzystwo Dobroczynne Dam Polskich.

${ }^{8}$ BCzwK, ew. 1120, A. Czartoryska, papiery osobiste. Lista imienna członkiń i lista opiekunek.

${ }^{9}$ BCzwK, ew. 1120, A. Czartoryska, papiery osobiste. 
nych z popierania działalności politycznej księcia Adama Czartoryskiego. Łączyli oni działalność polityczną z charytatywną budząc wśród emigrantów podejrzenia o próbę jednania sobie zwolenników za pieniądze ${ }^{10}$. W późniejszych latach lista dystrybutorów malała i w roku 1856 było ich tylko ośmiu. Niektórzy z panów współpracowali z Towarzystwem przez wiele lat. Do nich należeli: płk Walery Paprocki, ks. Komecki, hr. Franciszek Plichta przez 30 lat był kasjerem. Wieloletnim dystrybutorem pieniędzy był Antoni Cichocki ${ }^{11}$. Funkcję głównego dostawcy pełnił kapitan Józef Sawicki, a przez wiele lat nadzór nad magazynem pełnił ks. Tomasz Praniewicz. Rozdzielał żywność, odzież, narzędzia do pracy, opał itp. ${ }^{12}$

Ważną rolę w Towarzystwie spełniali lekarze dyżurujący. Ich zadaniem było udzielanie chorym emigrantom bezpłatnej medycznej porady. W znanych materiałach figuruje sześć nazwisk. Byli to: Ildefons Krysiński, Jan Fryderyk Matuszyński, Filip Kulawski, Stasiński, Aleksander Konstanty Jaślikowski i Szikalski13. Przyjmowali chorych, wypisywali recepty, a jeśli trzeba było udawali się na wezwanie do pacjentów.

Towarzystwo organizowało okresowe spotkanie, nazywane sesjami lub posiedzeniami. Początkowo bardzo często, nieregularnie co kilka dni, później raz w miesią$\mathrm{cu}$, zawsze w pierwszą sobotę. Wynikało to, prawdopodobnie z potrzeby załatwienia wielu spraw organizacyjnych i podejmowania decyzji wynikających z nadzwyczajnych okoliczności. Przykładowo w 1836 roku odbyło się 26 posiedzeń ${ }^{14}$. Podobnie było w latach 1837 i 1838. Miejscem posiedzeń od 1843 roku był Hotel Lambert, wcześniej mieszkanie księżnej Anny Czartoryskiej. Posiedzenia były zwyczajne i nadzwyczajne. Pierwsze były spotkaniami roboczymi, na nich omawiano aktualny stan finansów i rzeczy oraz potrzeby w zakresie pomocy. Tu zapadły decyzje o udzielenie proszącym pomocy, względnie jej odmówienie z braku pieniędzy, lub jeśli osoba nie kwalifikowała się do jej otrzymania. Zwykle na tych posiedzeniach czynił sprawozdanie magazynier oraz czytano raporty z przebiegu dobroczynnych przedsięwzięć opracowane przez kontrolerów wyłonionych spośród dystrybutorów. Sesje nadzwyczajne zwoływano rzadko, tylko wtedy, gdy zachodziła konieczność podjęcia nadzwyczajnych decyzji, o udzieleniu pomocy, a termin posiedzenia zwyczajnego był odległy. Jedno z takich posiedzeń w 1837 roku odbył się po otrzymaniu wiadomości z Londynu o tragicznym położeniu materialnym wielu emigrantów polskich tam się znajdujących. Inne zwołano by natychmiast udzielić pomocy dla kilku osób ciężko chorych ${ }^{15}$.

\footnotetext{
${ }^{10}$ L. Gadon, Z życia Polaków we Francji, Paryż 1883, s. 52.

${ }_{11}$ „Kronika Emigracji Polskiej”, t. 7, 1838, s. 41; BCzwK, ew. 1528b, Towarzystwo Dobroczynne Dam Polskich.

${ }^{12}$ „Noworocznik Demokratyczny”, t. 1, 1842, s. 116.

${ }^{13}$ BCzwK, ew. 1120, A. Czartoryska, papiery osobiste; „Kronika Emigracji Polskiej”, t. 6, 1837, s. 13; „Noworocznik Demokratyczny”, t. 1, 1842, s. 116 i t. 2, 1843, s. 179.

${ }^{14}$ „Kronika Emigracji Polskiej”, t. 4, 1836, s. 28, 88, 139, 197, 293, 294, 333.

${ }^{15}$ Tamże, t. 7, 1838, s. 40, 232, 227.
} 
Dotąd była mowa o strukturze organizacyjnej Towarzystwa Dobroczynności Dam Polskich - członkiniach i współpracownikach. Teraz chcemy się przyjrzeć pokrótce sposobowi zdobywania pieniędzy na działalność charytatywną. Sposobów było kilka, o nich wspomnieliśmy już wyżej. Najwięcej pieniędzy przynosiły „Bazary Polskie" organizowane każdego roku. Posiadały one swoistą specyfikę, małe prowizoryczne sklepiki prowadzone przez wytworne sprzedawczynie, zachęcające do kupowania uśmiechem i głośną reklamą. Oferowały bardzo różne towary, pochodzące i fantów, a wszystko działo się jak na zwykłym bazarze, wśród gwaru i tłumu kupujących. $\mathrm{Z}$ tą różnicą, że sprzedawczyniami i kupującymi były osoby wysoko urodzone, a nie szary tłum zwykłego bazaru. Na podstawie znanych nam źródeł nie jesteśmy w stanie odtworzyć pełnych dochodów z „Bazarów” za cały okres 30 lat intensywnej działalności Towarzystwa. Przeciętnie kształtowały się w granicach 12 do 20 tysięcy fr. Natalia Kicka w swoich pamiętnikach pisze, że dochody dochodziły do 20 tysięcy fr. Wiemy jednak, że w 1836 roku dochód z „Bazaru” wyniósł 11.499 fr., a w 1839 roku 23 tysiące fr. ${ }^{16}$ Zatem wielkość zysków bazarowych była bardzo różna. Na wielkość dochodów składał się nie tylko utarg ze sprzedanych przedmiotów i rzeczy, ale także dary pieniężne składane przez zwiedzających. Podane wyżej sumy były czystym dochodem, po odliczeniu wydatków na zorganizowanie „Bazaru" łącznie z reklamą. Koszty te wynosiły w różnych latach od 4 do 8 tysięcy fr. Zyski bazarowe stanowiły główną pozycję w budżecie Towarzystwa. Wszystkie inne dochody z kwest, bali, koncertów jedynie uzupełniały go do wysokości wydatków, które zamykały się w granicach do 30 tysięcy fr. ${ }^{17}$ Można zatem ustalić, że dochody i wydatki wahały się w granicach 20-30 tysięcy fr. rocznie, z wyjątkiem lat 18451846, kiedy uzyskano około 70 tysięcy fr. W ciągu 30 lat działalności Towarzystwa pod prezydencją księżnej Anny Czartoryskiej zebrano i rozdano sumę 951.970, 08 franków ${ }^{18}$. Pieniądze te rozdzielano $w$ trzech formach: jako pomoc $w$ naturze, w pieniądzach i na inne środki.

Pomoc $\mathrm{w}$ naturze to przede wszystkim przydział żywności, odzieży, bielizny i lekarstw oraz kąpiele lecznicze dla chorych. Wliczano tu także wydatki na mieszkanie, na zakup niezbędnych sprzętów do mieszkań i opał. Zdarzały się także wypadku zakupu narzędzi rzemieślniczych dla osób podejmujących pracę. Należy zauważyć, że dzienne wyżywienie w czasie napływu Polaków do Francji kosztowało od 1 do 2 franków. Taniej można było się wyżywić na prowincji, drożej natomiast w miastach. Do tego dochodziły opłaty za mieszkanie, ubranie i inne drobne rzeczy. Tymczasem żołd, jaki otrzymali uchodźcy od rządu francuskiego wynosił od 22 do 45 franków miesięcznie, a wielu z nich nie otrzymało żadnego zasiłku. Towarzystwo znając te dramatyczne często sytuacje, starało się w miarę możliwości temu zaradzić, mając przy tym ograniczone możliwości. Rozdawano zatem żywność

16 Tamże, t. 5, 1836-1837, s. 169, t. 7, 1838, s. 43 i t. 8, 1839, s. 108; „Trzeci Maj” 1839-1840, nr 4, s. 19; 1843-1844, nr 1, s. 494; „Wiadomości Polskie” 1857, nr 3, s. 9.

${ }^{17}$ BCzwK, ew. 1528b, Towarzystwo Dobroczynne Dam Polskich.

${ }^{18}$ W. Mickiewicz, Emigracja Polska 1860-1890, Kraków 1908, s. 119. 
w postaci biletów obiadowych wykupionych w określonych jadłodajniach. Najczęściej były to restauracje, z właścicielami których Towarzystwo zawierało umowy na określoną ilość posiłków. Obiad można było zjeść po okazaniu biletu otrzymanego od Towarzystwa ${ }^{19}$. W czasie zimy można było otrzymać dodatkowo gorącą zupę. Dodatkowo czasami rozdawano także bilety na mięso. Ta forma pomocy żywnościowej była pomyślana dla tych, którzy mogli osobiście udać się do określonej restauracji. natomiast dla tych, którym zdrowie na to nie pozwalało Towarzystwo płaciło całodzienne wyżywienie w miejscach przebywania - zakładach, pensjonatach itp. Dzienny koszt takiego wyżywienia wynosił 17 sous, tj. około jednego franka.

Nasuwa się w tym miejscu pytanie, jak duża liczba emigrantów korzystała $\mathrm{z}$ tej formy pomocy? Dysponując niekompletnymi źródłami, możemy jedynie w przybliżeniu określić wielkości pomocy żywnościowej udzielanej emigrantom przez Towarzystwo. Wiemy, że w pierwszym roku działalności wykupiono biletów obiadowych i całodziennego wyżywienia za 3760, 20 franków. Za tę sumę kupiono 3114 obiadów, za resztę całodzienne wyżywienie ${ }^{20}$. W następnym roku na bilety obiadowe wydano 2489, 80 franków, a bilety kosztowały po 80 lub 85 centów. Stąd wniosek, że liczba biletów niewiele się zmieniła. Znaczne zmniejszenie pomocy żywnościowej nastąpiło dopiero w latach 1837 i 1838, kiedy to Towarzystwo wykupiło zaledwie 1610 biletów żywnościowych ${ }^{21}$. Zdajemy sobie z tego sprawę, że liczby te nie są dokładne, dają jedynie wyobrażenie o wielkości pomocy dla emigrantów ze strony Towarzystwa. W latach późniejszych kwoty wydawane na bilety obiadowe były nieco większe, i tak w roku 1845 wydano kwotę 4973,95 fr., a dwa lata później 7750,97 fr., ale już w 1855 roku tylko $275,70 \mathrm{fr}$. W latach pięćdziesiątych wydawane były bilety na chleb. W roku 1855 zakupiono ich za kwotę 2944 fr. Zwiększa to sumę na żywność do poziomu, jaką wydawano wcześniej ${ }^{22}$. Jak często w ciągu miesiąca można było liczyć na taką pomoc? Według Budzyńskiego zupę i kawałek mięsa, a raczej bilety na nie rozdawano dwa razy w tygodniu. Bilety chlebowe, w ramach pomocy żywnościowej, były akcją doraźną w szczególnie trudnych sytuacjach dla niektórych emigrantów.

Inną formą pomocy, jaką podejmowało Towarzystwo w ramach akcji dobroczynnych, to przydzielanie odzieży, bielizny i obuwia. Sprawami tymi zajmował się specjalnie do tego powołany Magazyn. Za określoną sumę pieniędzy kupowane były ubrania i w miarę potrzeby rozdzielane najbardziej potrzebującym. Pieczę nad Magazynem sprawowała jedna osoba - od sierpnia 1837 roku był nią ks. Tomasz Proniewicz. Tu również możemy się posłużyć wielkością wydatków na odzież jedynie z kilku lat. W pierwszym roku działalności wydano na ten cel 2885,50 fr., co przy ogólnych wydatkach stanowiło $23 \%$, trochę mniej na żywność. W latach następnych kwoty wydawane na ubrania wyraźnie maleją i w latach 1855-1856 wynosiły

\footnotetext{
19 „Kronika Emigracji Polskiej”, t. 3, 1835, s. 66 i t. 7, 1838, s. 228-230.

${ }^{20}$ Tamże, t. 3, 1835, s. 66.

${ }^{21}$ Tamże, t. 6, 1837, s. 345,346 i t. 7, 1838, s. 40-42 i 228-230.

${ }^{22}$ BCzwK, ew. 1528b, Towarzystwo Dobroczynne Dam Polskich.
} 
1215 fr., co stanowiło zaledwie 6\% ogólnego budżetu ${ }^{23}$. Widać z powyższego, że ten sposób pomocy emigrantom nie był najważniejszy w wydatkach Towarzystwa. Ważniejsza była pomoc żywnościowa.

Dużym wydatkiem Towarzystwa była pomoc chorym, udzielana w postaci leków, porad medycznych i kąpieli leczniczych zalecanych przez lekarzy. Jak wspomnieliśmy wyżej Towarzystwo w swoim gronie posiadało kilku lekarzy, którzy udzielali bezpłatnej pomocy i wypisywali chorym recepty. Pracowali bezinteresownie, ale jedynie na terenie Paryża. Tylko ich recepty były finansowane przez Towarzystwo. Niewiele zatem emigrantów z prowincji mogło skorzystać z tej formy pomocy, ponieważ trzeba było przyjechać do Paryża. Dwaj paryscy aptekarze realizowali recepty wystawiane przez lekarzy pracujących dla Towarzystwa, tj. apteki: Johnsona i Habera ${ }^{24}$. Czasami aptekarze ci umarzali rachunki za leki, odciążając w ten sposób kasę Towarzystwa. W latach czterdziestych zeszłego stulecia do grona aptekarzy zaopatrujących emigrantów w leki dołączyła apteka pana Sokołowskiego - Polaka. Zawarcie z nim umowy mogło się wiązać ze zwiększonym zapotrzebowaniem na leki lub wspieraniem rodaka, który otworzył własną aptekę. W latach sześćdziesiątych wydatki na lekarstwo zamykały się kwotą 2 tysięcy franków rocznie ${ }^{25}$. Brak danych co do lat wcześniejszych, nie pozwala na dokładne podanie sum wypłacanych na lekarstwa. Dodatkowo każdego roku na kąpiele lecznicze wydawano około 1 tysiąca franków. W latach 1845-1846 na lekarstwa, kąpiele i bandaże wydano 3200 fr. Tyle samo wydawano i w latach następnych. Ogólne wydatki na żywność, odzież i lekarstwa w latach 1834-1856 wahały się w granicach od 7 do 16 tysięcy franków. Wliczone są w to także wydatki na narzędzia pracy.

Nieco inaczej rozdzielana była pomoc pieniężna. W pierwszym rzędzie otrzymywały ją dzieci emigrantów. W latach 1835-1836 wydano 1228 fr., licząc na każde dziecko 5 fr. miesięcznie. Łatwo można obliczyć, że z pomocy tej rocznie korzystało dwadzieścioro dziecie ${ }^{26}$. W 1836 roku Towarzystwo dodatkowo zobowiązało się wypłacić po 5 fr. dla trzydzieściorga dzieci ze szkółek w Nancy i Orleanie. Wcześniej dzieci te otrzymywały pomoc od Towarzystwa Naukowej Pomocy, kierowanego przez Ignacego Domeykę. Budżet tego Towarzystwa wyczerpał się i dlatego pomoc dla trzydzieściorga dzieci przejęły Damy Polskie i kontynuowały ją przez trzy kolejne lata. W roku 1837 na pomoc dla dzieci przeznaczono 5500 fr., zachowując miesięczną stawkę 5 fr. Korzystało zatem w ciągu roku ponad dziewięćdziesięcioro dzieci z pomocy Towarzystwa Dobroczynności Dam Polskich. Do ubiegania się o taką pomoc uprawnione były w pierwszym rzędzie sieroty, półsieroty, dzieci kalekie lub rodziców i opiekunów chorych, a nadto dzieci z licznych rodzin. nie przyznawano zapomogi dzieciom powyżej 12. roku życia z wyjątkiem dzieci uczących się w wyżej wymienionych szkołach, dzieciom powierzonym na wychowanie

\footnotetext{
${ }^{23}$ Tamże.

${ }^{24}$ BCzwK, ew. 1120.

${ }^{25}$ BCzwK, ew. 1528b.

${ }^{26}$ „Kronika Emigracji Polskiej”, t. 5, 1836-1837, s. 170.
} 
i urodzonym z małżeństw zawartych na emigracji ${ }^{27}$. Jak wynika $\mathrm{z}$ analiz sprawozdań finansowych, którymi dysponujemy, suma na pomoc dla dzieci każdego roku wzrastała. W roku 1838 osiągnęła 6500 fr. i na tym poziomie utrzymywała się przez kilka lat. Dopiero w latach 1845-1847 wzrosła o około tysiąca franków ${ }^{28}$.

Inną formą pomocy pieniężnej było wspomaganie osób chorych i kalekich oraz tych emigrantów, których los nagle się pogorszył. Osoby te otrzymywały określone sumy pieniędzy do własnego rozporządzenia. Wysokości tych sum zależne były od stopnia potrzeb danej osoby. O pomoc taką należało się zwrócić do Towarzystwa pisemnie, uzasadniając potrzebę dokumentami świadczącymi o kalectwie i niezdolności do pracy lub nieotrzymywaniu pomocy od rządu francuskiego. Nie wszystkie prośby z terenu całej Francji były załatwiane pozytywnie.

Kwoty pieniędzy przesyłane potrzebującym były bardzo zróżnicowane i zależały między innymi od możliwości płatniczych Towarzystwa. Najczęściej były to zasiłki jednorazowe i miesięczne. Te ostatnie w granicach 20-30 fr. na miesiąc, jednorazowe 50 fr. na osobę będącą w gwałtownej potrzebie. Przykładowo w roku 1841 udzielono 112 zapomóg na sumę 1625 fr. W następnym roku wsparto w ten sposób 70 osób sumą 1340 fr. ${ }^{29}$ w roku 1843 wypłacono 3392 fr. dla 168 chorych. Rozpiętość wypłat pieniężnych w latach 1834-1855 była bardzo duża i wahała się od 2842 do 8928 fr. Średnio każdego roku na pomoc finansową dla potrzebujących pomocy Towarzystwo wydawało około $20 \%$ swego budżetu.

Innym rodzajem wsparcia było pokrywanie kosztów podróży. Najczęściej otrzymywali taką pomoc ludzie chorzy, którzy z polecenia lekarza udawali się do uzdrowisk w celu podratowania zdrowia. Zwracano też koszty związane ze zmianą miejsca zamieszkania lub z poszukiwaniem pracy. Sumy, jakie jednorazowo w tych sytuacjach Towarzystwo zwykło wypłacać wahały się od 15 do $30 \mathrm{fr} .{ }^{30}$ Innym przykładem może być Soter Kośmiński, który w latach 1835-1840 na podróże do wód otrzymał 178 fr. wsparcia. W roku 1842 dla 31 emigrantów poszukujących pracy w różnych miejscowościach Francji wypłacono na podróże 327 fr. W następnym roku na ten sam cel wydatkowano podobną sumę. Nie zawsze kwoty te były tak niskie, np. w roku 1847 wypłacono łącznie na wyjazdy lecznicze i za pracą $2326 \mathrm{fr}$.

W pierwszych latach wychodźstwa polskiego była duża śmiertelność wśród emigrantów polistopadowych. Spowodowane to było często niedożywieniem i warunkami $\mathrm{w}$ jakich przebywali $\mathrm{w}$ tzw. dépo. Tylko $\mathrm{w}$ jednym, najgorszym pod tym względem roku 1842 we Francji zmarło 550 Polaków. najczęściej osoby umierające nie pozostawiały po sobie zaoszczędzonych pieniędzy, którymi można było pokryć koszta pogrzebu. Często więc Towarzystwo brało na siebie ciężar finansowy związany z pochówkiem. Opłata grabarza w takich wypadkach wynosiła do $60 \mathrm{fr}$.

27 Tamże, t. 6, 1837, s. 138-139.

${ }^{28}$ Tamże, t. 7, 1838, s. 41 i 225; „Trzeci maj” 1847-1848, nr 15, s. 640; 1840-1841, nr 44-45, s. 640 i 217.

29 „Trzeci Maj” 1840-1841, nr 44-45, s. 219; 1842, nr 41-42, s. 458.

30 Tamże, 1839-1840, nr 46, s. 198. 
Niestety nie wiemy w ilu i na jaką sumę Towarzystwo partycypowało w pogrzebach współziomków ${ }^{31}$.

Sumując wszystkie przedsięwzięcia finansowe Towarzystwo, obejmujące stałą pomoc dla dzieci, jednorazowe wsparcia dla chorych, znajdujących się chwilowo w trudnych sytuacjach finansowych na skutek życiowych niepowodzeń, na konieczne przejazdy i pogrzeby, za okres do 1856 roku, zamykają się średnio rocznie sumą 12 tysięcy franków. W tym okresie najmniejsze wypłaty gotówkowe wynosiły około 4,5 tysiąca franków, natomiast największe około 18 tysięcy franków, co stanowiło do $50 \%$ wszystkich wydatków. Sądząc po wielkości potrzebujących pomocy i liczbie emigrantów, an terenie tylko Francji, to stwierdzić należy, że sumy te były niewielkie i zaspokajały znikomą część wszystkich potrzeb. Stosunkowo duże kwoty przeznaczano, w niektórych latach, które kwalifikujemy jako inne wydatki. Np. w roku 1836 do Marsylii przybyła spora grupa polskich emigrantów z Krakowa, większość z nich nie posiadała żadnych środków do życia. Towarzystwo udzieliło im wsparcia finansowego do czasu załatwienia pomocy rządowej. Pomagano także emigrantom w Anglii, powracającym w 1837 roku z Hiszpanii i z nieudanej wyprawy frankfurckiej. Później w 1844 roku przybyli do Francji więźniowie Magdeburga, którzy nie mieli żadnych pieniędzy. Nie znając języka francuskiego znaleźli się w bardzo trudnej sytuacji. We wszystkich tych wypadkach Towarzystwo ułatwiało polskim przybyszom start życiowy dając wsparcie finansowe i ułatwiając znalezienie pracy ${ }^{32}$. W pomocy dla przebywających grup w latach późniejszych uczestniczyły także inne organizacje polityczne, łącznie z lewicowymi. Damy Polskie przekazując głównie bilety żywnościowe.

$\mathrm{Na}$ pomoc Towarzystwa mogły liczyć również inne organizacje wspierające emigrantów w ich niedoli. Z pomocy tej korzystało Towarzystwo Naukowej Pomocy. Każdego miesiąca przekazywano kwotę 100 fr. na wsparcie „Domu Przytułku i Pracy" założonego w 1844 roku przez Zmartwychwstańców - Kajsiewicza i Terleckiego. Towarzystwo służyło swoją pomocą Radzie Gospodarczej założonej w 1849 roku przez sekcję paryską Towarzystwa Demokratycznego Polskiego. Rada miała na celu pomoc dla nowo przybyłych do Francji Polaków po wydarzeniach 1848 roku. $\mathrm{Na}$ jej konto Towarzystwo wpłacało miesięcznie po $200 \mathrm{fr}^{33} \mathrm{Z}$ inicjatywy księżnej Anny Czartoryskiej uczestniczyło Towarzystwo tworzeniu i utrzymaniu pensjonatu i szkoły dla nauczycielek i wychowawczyń, nazywanym powszechnie Instytutem Panien Polskich ${ }^{34}$.

Te kilka przykładów wyraźnie wskazują, że Towarzystwo Dobroczynności Dam Polskich wspierało nie tylko osoby, ale także wszelkie inicjatywy i działania innych organizacji w zakresie niesienia pomocy rodakom. Było to zrozumiałe, ponieważ zmniejszała się przez to liczba petentów Towarzystwa i zapewniało to pomoc

\footnotetext{
${ }^{31}$ „Kronika Emigracji Polskiej”, t. 7, 1838, s. 41.

32 „Demokrata Polski” 1844-1845, nr 14, s. 111.

33 Tamże, 1849-1850, nr 27, s. 109.

${ }^{34}$ A. Lewak, Czasy Wielkiej Emigracji..., t. 3, s. 193-233.
} 
większej liczbie potrzebujących. Trzeba też zauważyć, że w zakresie charytatywności istniała wyjątkowa solidarność wśród emigracji mimo różnic politycznych. Wynikało to z racji nadrzędności celu, jaki przyświecał działaczom.

Dla pełnego obrazu niesienia pomocy emigrantom należy wspomnieć o inicjatywie Wydziału Historycznego Towarzystwa Historyczno-Literackiego. Chodziło o płatne kopiowanie materiałów do historii Polski przechowywanych w Bibliotece Królewskiej w Paryżu. Można tu było zarobić do 20 fr. miesięcznie. Towarzystwo na ten cel przeznaczało 1000 fr. rocznie dla 19 osób. Brak informacji czy były inne jeszcze tworzenia miejsc pracy przez Towarzystwo ${ }^{35}$, ale i te wskazują na dużą różnorodność podejmowanych inicjatyw. Można też powiedzieć, że Towarzystwo nie działało w odosobnieniu, w zamkniętym swoim kręgu, lecz było otwarte na współpracę wobec innych inicjatyw charytatywnych.

\section{Informacja o źródłach Towarzystwa Dobroczynności Dam Polskich znajdujących się w Bibliotece Polskiej w Paryżu}

1. Pol. księga $30 \times 20$, s. 165, opr. płótno (str. nie zapisane 4-5 i 151-161), stan zachowania bardzo dobry

Protokół Towarzystwa Dobroczynności Dam Polskich w Paryżu 1834 (od 12 marca do 27 grudnia)

Między innymi: Ustawy Towarzystwa Pomocy dla nieszczęśliwych Polaków w Emigracji zawiązanego d. 12 marca 1834 w Paryżu, s. 1-3; Prawa dodatkowe do ustawy Towarzystwa Pomocy, przyjęte na posiedzeniu 22 marca 1834, s. 3; Skorowidz posiedzeń Towarzystwa, s. 6; Spis członków Towarzystwa i ich adresy: Prezydująca księżna Czartoryska, siostry podpisane na akcie zawiązania: 1) Hrabina Platerowa, 2) Księżna Ogińska, 3) Pani Rautenstrauch, 4) Pani Wołowska, 5) Pani Hoffmanowa. Siostry przybrane: 6) Pani Łuszczewska, 7) Pani Mickiewiczowa, 8) Pani Watpol. Siostry korespondentki: 1) Jenerałowa Małachowska, 2) Pani Godebska, 3) Pani Staniewiczowa, 4) Pani Szyrmina, 5) Pani Schwartz, 6) Pani Józefa de Rottenmund, 7) Pani Dubois. Bracia korespondenci: Henryk Nakwaski, Marian Brzozowski, pułkownik Janowicz, ksiądz Dąbrowski, pułkownik Koncewicz. Dystrybutorowie wezwani na pierwszym posiedzeniu: 1) jenerał Pac, 2) pułkownik Łagowski, 3) Radca Stanu Plichta, 4) Wolski, 5) Bożewski, 6) Grzymała, 7) Jełowicki, 8) dr Marcinkowski, 9) Olizar, 10) ksiądz Skórzyński, 11) Stępowski, 12) Żarczyński, 13) Woroniecki, 14) Domeyko, 15) Skarżyński. Dystrybutorzy przybrani: 16) dr Kryziński, 17) Hoffman, 18) Dworzaczek, 19) Weissenhoff, 20) Wołowicz, 21) Błotnicki, 22) Gratkowski, 23) Dobrowolski, 24) Łuszczewski, 25) Bystrzanowski. na stronach 162-163 - dochód 15.925, 60 fr., 165 - wydatki 9.967, 65 fr; posiedzeń od 1 do 33 .

35 „Trzeci maj” 1844, nr 52, s. 218. 
2. Fran. księga 22×19, k. 135, opr. płótno, str. nie zap. 11-17, 113-135 (stan bardzo dobry).

Rok 1834. Początek założenia i organizacji Towarzystwa Dobroczynności Dam Polskich w Paryżu, pierwsze posiedzenie Towarzystwa 12 marca 1834 r. Księga protokołów od marca do lipca $1834 \mathrm{r}$.

Między innymi: Reglements de la société de secours pour les polonais indigens, k. 1-7; Articles additionnels aux reglements de la société de secours pour les polonais indigens, k. 8-9.

3. Pol. fran. księga $31,5 \times 20$, s. 262 , opr. pł. sk. (stan dobry)

Protokół Towarzystwa Dobroczynności Dam Polskich w Paryżu 1835, 1836 (od 10 stycznia 1835 do 30 października 1836, posiedzenie 34-81).

Dalszy ciąg protokołu posiedzeń Towarzystwa Polek w Paryżu założonego w d. 12 marca 1834 pod przewodnictwem i na wezwanie księżnej Anny Czartoryskiej w celu wspierania nieszczęśliwych rodaków w Emigracji. jest w tym woluminie przerwa od 2 lipca do 12 października 1836 r. Przez ten czas zwyczajne sesje Towarzystwa były zawieszone. Bieżące czynności załatwiała delegacja. Protokół jej umieszcza się an początku tomu następnego.

Między innymi: Skorowidz posiedzeń Towarzystwa. na str. 33 wklejona kartka z wyjaśnieniami sekretarza i ekonomisty. Po str. 46 wklejone kwartalne sprawozdanie magazynu Towarzystwa - wsparcia (od dnia 1 stycznia do 1 kwietnia 1835 r.)). Po str. 50 wszyta broszura „Premier Compte Rendu de l'Association Bienfaisance des Dames Polonaises à Paris". Paris 1835 (zawiera wykaz ofiarodawców oraz rozliczenie z wydatków). Wklejony jest też raport magazynowy po str. 56 . Na str. 74 bilet-zaproszenie na Veute. Na str 76 wklejona informacja o finansach Towarzystwa Dobroczynności Dam Polskich o posiadanych funduszach w Banku Jelskiego. Na str. 77 wklejony raport kwartalny magazynu wsparcia i raport tygodniowy magazynu. Str. 81 wykaz pozostałości w kasie. Str. 88 zestawienia wydatków. str. 126 wklejone „Zdanie sprawy z bilansów”. Str. 137 wklejone „Stan magazynu i raport dwu tygodniowy" oraz wykaz zakupionych biletów [do jadłodajni]. Str. 142 wklejone informacje o rzeczach rozdanych i zakupionych. Str. 147 wklejone informacje o rzeczach rozdanych i zakupionych, toż na str. 161 . Str. 163 wklejony raport dwu tygodniowy. Str. 165 wklejone informacje o rzeczach rozdanych i zakupionych. Str. 173 wklejone informacje „czym zajmuje się Towarzystwo Dam Polskich”. Str. 175 wklejone informacje o rzeczach rozdanych i kupionych. Str. 177 raport dwutygodniowy. Str. 180 informacje o rzeczach rozdanych. Str. 182 wklejony raport dwutygodniowy. Str. 188 informacje o płatności Towarzystwa. Str. 195 wklejone informacje o stanie kasy Towarzystwa i o stanie magazynu. Str. 198 wklejony raport czterotygodniowy o wypłatach i wydatkach. Str. 205 wklejone informacje o stanie kasy. Str. 206 wklejony raport dwutygodniowy o wpłatach i wydatkach. Str. 210 wklejone: stan kasy Towarzystwa z d. 21 V 1836 r. i raport magazynowy z 21 V 1836. Str. 218 wklejone: Stan kasy z 4 VI 1836 r. oraz informacje o rozdanych rzeczach i zakupionych do 3 VI 1836 r. Str. 219 wklejony: Rachunek podany przez Ignacego Domeykę z 4 VI 
1836 r. i raport tygodniowy. Str. 225 wklejony stan kasy Towarzystwa Pomocy Dam Polskich w dniu 18 VI 1836 r. Str. 226 wklejone: Raport tygodniowy oraz informacje o rozdanych i zakupionych rzeczach z magazynu w dniu 4 VI [1836 r.] Str. 232 wklejone: Stan kasy Towarzystwa w d. 2 lipca 1836 r. oraz informacja, że od 18 czerwca do 2 lipca z magazynu nie rozdano nic. Str. 236 wklejone: Informacja, że Towarzystwo zawiesza czynności z powodu oddalenia się z Paryża kilku Dam do składu należących i postanawia zawiesić zwyczajne posiedzenie na 3 miesiące. Str. 237 wklejony raport magazynowy Towarzystwa od 2 lipca do 8 października $1836 \mathrm{r}$. Str. 239 wklejony raport 8-tygodniowy. Str. 246 wklejony wykaz stanu magazynu Towarzystwa od 10 listopada 1835 do 1 października 1836 r. Str. 247 wklejony raport magazynowy z 12 X [1836 r.]

4. Pol. fran. księga XIX w. 30×19,5 k. 215, opr. płótn., nie zapisanych k. 16 i 210-215.

Protokół Towarzystwa Dobroczynności Dam Polskich w Paryżu 1836, 1837, 1838 (od 26 listopada 1836 do 3 marca 1838).

Dalszy ciąg protokołu posiedzeń Towarzystwa Dobroczynności Dam Polskich w Paryżu założonego 15 marca 1834 r. na wezwanie i pod przewodnictwem księżnej Anny z Sapiechów Czartoryskiej w celu wspierania biednych rodaków w Emigracji. od dnia 26 listopada 1836 r. do 3 marca 1838 r., protokóły posiedzeń od 82 do 116. W tym woluminie na początku wpisany jest protokół delegacji Towarzystwa Dobroczynności Dam Polskich od 16 lipca do 24 września 1837 r. Nadto delegacja istniała zaraz po sesji zawiązania 2 lipca 1836 r. aż do sesji 12 października 1836 r. Kwitów delegacji nie ma w kwitariuszu k. 1-15.

Między innymi: Skorowidz sesji z wymienieniem stronicy protokółu, od której zaczyna się każda sesja, szczególnie i z wyróżnieniem daty. k. 18 wklejona kartka zawierająca informacje o stanie kasy w d. 26 listopada 1836 r. k. 23 wklejony list M. de Bonnes. K. 24 wklejona kartka zawierająca informacje o stanie kasy Towarzystwa... z dnia 10 XII 1836 r. K. 25 luźna kartka zawierająca spisy rzeczy zakupionych i wydanych z magazynu Towarzystwa... w czasie od 12 listopada do 10 grudnia [1836 r.]. K. 26 luźna kartka „Raport dziesięciotygodniowy” o zakupach z 10 XII 1836 r. K. 32 luźna kartka „Sprawozdanie kwartalne magazynu dobroczynności” od dnia 1. października 1836 r. do 1 . stycznia 1837 r. oraz kartka wklejona „Raport dwutygodniowy” z d. 31 grudnia 1836 r. o zakupach. K. 33 luźna kartka „Stan kasy Towarzystwa..." z d. 31 grudnia 1836 r. K. 35 luźna kartka zawierająca informacje o wpływach i wydatkach Towarzystwa... w roku 1836 oraz karta wklejona zawierająca „Stan kasy Towarzystwa... w dniu 14 stycznia 1837”. K. 35 karta wklejona zawierająca „Ostatni stan kasy” 14 I 1837. K. 37 karta wklejona „Kwesta po kolendzie w Paryżu d. 22 grudnia 1836 r.” K. 38 karta wklejona „Raport dwutygodniowy” d. 14 I 1837. K. 47 karta wklejona „Stan kasy Towarzystwa...” w d. 28 stycznia 1837 r. i „Przychód pieniężny do kasy i rozchód” styczeń 1837 r. K. 58 karta wklejona „Stan kasy Towarzystwa...” w d. 25 lutego 1837 r., karta luźna „Wykaz dwutygodniowy magazynu Towarzystwa...” od 28 I do 25 II [1837]. K. 63 luźna kartka „Stan kasy Towarzystwa...” w d. 11 marca 1837 r. K. 71 luźna „Raport czterotygodniowy” 
z d. 25 marca 1837 r. oraz karta wklejona ,wykaz miesięczny Towarzystwa...” od posiedzenia w dniu 25 lutego do dnia 25 marca [11837] (rozdano, kupiono, stan). K. 75 luźna kartka „Sprawozdanie kwartalne - stan magazynu od 1 stycznia do 1 kwietnia 1837 roku”. Wklejona karta „Stan Towarzystwa... w dniu 8 kwietnia 1837 r.” K. 82 luźna kartka „Stan kasy Towarzystwa... w d. 22 kwietnia 1837 r.” i „Wykaz czterotygodniowy magazynu Towarzystwa od posiedzenia w dniu 25 marca do 22 kwietnia” [1837]. K. 84 wszyta broszura „Troisiéme Compte Rendu de l'Association de Bienfaisance des Dames Polonaises à Paris". Paris 1837 (po francusku prezeska Anna Czartoryska daje rozliczenie finansowe i sprawozdanie z działalności). K. 86 wklejona karta „Wykaz dwutygodniowy magazynu Towarzystwa... od ostatniego posiedzenia w dniu 12 kwietnia do 6 maja 1837 r.” K. 87 wklejona karta „Stan kasy Towarzystwa... w d. 6 maja 1837 r.” K. 91 luźna kartka „Wykaz dwutygodniowy magazynu Towarzystwa... od ostatniego posiedzenia w dniu 6 maja do dnia 20 maja 1837”. K 93 luźna karta (jak wyżej od 20 V do 31 VI 1837). Wklejona informacja o finansach. K. 101 luźna kartka „Stan kasy Towarzystwa... d dniu 17 czerwca 1837 r.” K. 107 wklejone sprawozdanie kwartalne magazynu od 1 IV do 1 VI 1837 r. K. 108 broszura luźno włożona „Quatriéme compte rendu de l'Association de Bienfaisance des Dames Polonaises à Paris 1838" (Sprawozdanie Czartoryskiej z przychodów i rozchodów Towarzystwa...) K. 115 luźna kartka „Stan kasy Towarzystwa w d. 15 lipca 1837 r.”, „Wykaz dwutygodniowy magazynu Towarzystwa...” (1 lipca do 15 lipca [1837]). Przyklejony rachunek na 500 fr. przeznaczonych przez Towarzystwo Dam Polskich na wspieranie rodaków przybyłych z Hiszpanii 15 VII [1837]. K. 122 wklejony „Wykaz dwutygodniowy magazynu 15 VII-1 VIII 1837 r.” K. 123 wklejony „Raport czterotygodniowy d. 7 lipca 1837 r.” K. 137 luźna kartka, notatka o pożywieniu z kasy 300 fr. gen. Wronieckiemu, na zapłacenie pensji gospodyni 250 fr. oraz właścicielowi domu zdrowia, gdzie przebywał generał 140 fr. Rozliczenie do końca roku (bez daty) oraz pismo ekonomistów Towarzystwa... o stanie ksiąg kasowych. K. 142 wklejona kartka „raport sześciotygodniowy z d. 5 VIII 1837 r.” oraz kartka luźna „Stan kasy Towarzystwa... w d. 21 października 1837 r.” K. 152 karta luźna „Raport czterotygodniowy”. K. 156 wklejony list otwarty informujący o Towarzystwie księżnej Czartoryskiej z d. 1 octobre 1837 (język francuski). K. 157 karta wklejona „Stan kasy Towarzystwa w d. 4 listopada 1834 r.?” Wykaz rozdanych i nabytych rzeczy do magazynu od 17 sierpnia do 17 listopada $1837 \mathrm{r}$. K. 162 wklejone „Agence Générale de Placement des Employés, Ouvriers 35 Domestiques” oraz „Stan kasy Towarzystwa... w d. 18 listopada 1837 r.” „Informacja o kupionych i wydanych rzeczach z magazynu od 4 listopada do 18 listopada 1837 r." K. 163 wklejony „Raport czterotygodniowy z d. 21 października 1837 r.” K. 167 „Stan kasy Towarzystwa... w d. 2 grudnia 1837 r.” K. 171 luźna kartka „Wykaz czterotygodniowy magazynu Towarzystwa od dnia 18 listopada do 16 grudnia 1837 r." oraz wklejona kartka „Stan kasy Towarzystwa... w d. 16 grudnia 1837 r.”. Wklejony ,raport czterotygodniowy od 18 listopada do 16 grudnia 1837 r.” K. 175 luźna karta „raport czterotygodniowy od 16 grudnia 1837 do 8 stycznia 1838”. Wklejony 
raport „Kupiono do magazynu i rozdano od 16 grudnia 1837 do 6 stycznia 1838 r.” K. 184 luźna kartka „raport z przychodu i rozchodu magazynu Towarzystwa... od dnia 1 lipca 1837 do 10 stycznia 1838 r.” K. 193 wklejony „Raport dwutygodniowy rozchodu i przychodu pieniędzy” 27 I 1838. K. 200 luźny „Raport dwutygodniowy od 3 do 17 lutego 1838 r.” K. 206 luźna kartka „Sprawozdanie finansowe z wyprzedaży w Bazarze z balu danego na dochód funduszów Towarzystwa Dam Polskich w roku 1838”. K. 207 luźna kartka „Raport czterotygodniowy wydatków...” 12 luty 1838 r. „Stan kasy Towarzystwa... w d. 3 marca 1838 r.” „Spis książek ofiarowanych Towarzystwu Literackiemu przez Towarzystwo Dam Polskich".

5. Pol. XIX w. księga $30 \times 20$, k. 142, opr. płótno (pomyłka w numeracji od k. 135 na 235). kart niezapisanych 4.

Protokół Towarzystwa Dobroczynności Dam Polskich w Paryżu 1838, 1839, od 17 marca 1838 do 9 marca 1839 . Z dniem 15 marca 1838 roku rozpoczął się piąty rok istnienia Towarzystwa Dobroczynności Dam Polskich w Paryżu (posiedzenia 117-139).

Między innymi: K. 4 wklejony „Stan kasy Towarzystwa w dniu 27 marca 1838 r.” K. 6 wklejony „Raport czterotygodniowy od 17 III 1838 r.” K. 8 wklejony „Stan kasy Towarzystwa... w d. 31 marca 1838 r.” K. 14 wklejony „Stan kasy Towarzystwa... w d. 14 kwietnia 1838 r.” K. 20 wklejony „Stan kasy Towarzystwa... w d. 28 kwietnia 1838 r.” K. 22 wklejony „Raport sześciotygodniowy od 17 marca do 28 kwietnia 1838 r.” K. 26 wklejony „Stan kasy Towarzystwa... w d. 12 maja 1838 r.” K. 27 wklejone: „Raport pieniężny od dwóch miesięcy tak przychodu jak i rozchodu na effekta magazynowe Towarzystwa... od 3 III-12 V 1838 r.”, „Raport piętnastodniowy od 28 IV do 12 V 1838 r.” K. 33 wklejone: „Stan kasy Towarzystwa... w d. 26 maja 1838 r.”, „Raport piętnastodniowy od 12 maja do 26 maja 1838 r.” K. 39 wklejone notatki odręczne z rozliczeń finansowych. „Stan kasy Towarzystwa... w d. 9 czerwca 1838 r.”, „Raport piętnastodniowy od 26 maja do 9 czerwca 1838 r.” K. 48 wklejone „Raport dwumiesięczny tak rozchodu jak przychodu z pieniędzy na zakupienie effektów do magazynu Towarzystwa... 12 V 1838 r.”, „Raport miesięczny od 9 VI do 7 VII 1838 r.” K. 49 wklejony „Stan kasy Towarzystwa... w d. 7 lipca 1838 r.” K. 51 wklejony spis kwitów przesłanych przez dra Błotnickiego d. 23 sierpnia 1838 r. K. 58 wklejone: „Stan kasy Towarzystwa... w d. 4 sierpnia 1838 r.”, „Raport miesięczny z pieniędzy tak przychodu jak rozchodu na zakupienie effektów do magazynu Towarzystwa... 18 lipca 1838 r.”, „Raport czterotygodniowy od 7 lipca do 4 sierpnia 1838 r.” K. 66 wklejony „Raport pieniężny miesiąca sierpnia tak z przychodu jak rozchodu na zakupienie effektów do magazynu Towarzystwa... 4 sierpnia 1838 r.", „Raport czterotygodniowy od 4 VIII do 1 IX” [1838]. K. 71 rewers wklejony „Stan kasy Towarzystwa... w d. 6 października 1838 r.” K. 72 wklejone: „Raport pięciotygodniowy pieniężny tak przychodu jak rozchodu na zakupienie effektów do magazynu Towarzystwa... 1 IX 1838 r.” i „Raport pięciotygodniowy od 1 września do 6 października” [1838]. K. 83 rewers wklejony „Raport czterotygodniowy pieniężny tak przychodu jak rozchodu na zakupienie effektów do magazynu Towarzystwa... 
15 X 1838 r.” oraz „Raport czterotygodniowy od 6 X do 3 XI 1838 r.” K. 90 wklejony „Stan kasy Towarzystwa... w d. 17 listopada 1838 r.” K. 95 wklejony „Stan kasy Towarzystwa... w d. 1 XII 1838 r.” K. 101 wklejony „Raport czterotygodniowy pieniężny, tak przychodu, jak rozchodu na zakupienie effektów do magazynu Towarzystwa... d 3 do 20 XI 1838 r.”, ,Raport czterotygodniowy od 3 XI do 1 XII 1838 r.” K. 104 wklejony „Stan kasy Towarzystwa... w d. 15 grudnia 1838 r.” K. 109 wklejone notatki o finansach ekonomisty Plichty oraz „Stan kasy Towarzystwa... w d. 5 stycznia 1839 r.” K. 119 wklejone: „Raport siedmiotygodniowy z pieniędzy, tak przychodu jak rozchodu na zakupienie effektów do magazynu Towarzystwa... 1839 r.” oraz „Raport siedmiotygodniowy od 1 XII 1838 do 19 I 1839 r.” K. 128 wklejony „Stan kasy Towarzystwa... w d. 16 I 1839 r.” K. 131 wklejone „Raport miesięczny z pieniędzy, tak przychodu jak rozchodu na zakup effektów magazynowych Towarzystwa... w 1839 r.” oraz „Raport miesięczny z biletów obiadowych d 19 I do 16 II 1839 r.” K. 141 wklejony „Raport tygodniowy pieniężny z przychodu i rozchodu na zakup effektów magazynowych Towarzystwa... 9 III 1839 r.” i „Raport trzytygodniowy z biletów [obiadowych] od 16 II do 9 III" [1839].

6. Pol. XIX w., księga 30×19,5, k. 185, opr. płplt., kart niezapisanych i nie fol. 4 .

Protokół Towarzystwa Dobroczynności Dam Polskich w Paryżu 1839 i 1840. Od 23 marca 1839 do 13 marca 1840. Posiedzenie od 139 do 161.

Między innymi: K. 1 wklejony „Stan kasy Towarzystwa... w d. 23 marca 1839 r.” K. 13 wklejony „Stan kasy Towarzystwa... z d. 6 kwietnia 1839 r.” K. 20 wklejony „Raport sześciotygodniowy od 9 III do 20 IV 1839 r.” oraz „Raport sześciotygodniowy z pieniędzy, tak przychodu jak rozchodu na zakupienie effektów do magazynu Towarzystwa... 20 IV 1839 r.” K. 28 wklejony „Obrachunek roczny magazynu od d. 4 kwietnia 1838 po dzień 27 kwietnia 1839 r., co do różnych effektów, biletów obiadowych i innych”. K. 29 wklejony „Stan kasy Towarzystwa... w d. 18 maja 1839 r." K. 42 wklejony brudnopis uwiadomienia ziomków o nie udzielaniu pomocy udającym się do wód mineralnych. K 44 wklejony „Stan kasy Towarzystwa... w d. 1 czerwca 1839 r.” K. 46 wklejony rachunek „Pieniądze przeznaczone z Towarzystwa Dobroczynności Dam Polskich dla ziomków słabych na prowincji, na ręce Sawockiego dane do posłania w dniu 18 maja 1839 r." Dla Trawińskiego w Nowym Jorku fr. 20, Szafrańskiego w Bourges fr. 25, Dąbrowskiego w Vierron fr. 20, Undzewicza w Angouline fr. 15, Kopernickiego w Daguignan fr. 30, Płosiskiego w Toulon fr. 20, Grabowskiego w Laval fr. 20, Darkowskiego w Blaurais fr. 25, Komorowskiego w Macin fr. 20, razem 195 fr. K. 47 wklejony „,Raport sześciotygodniowy od 20 IV do 1 VI 1839 r.” $i$ „Raport sześciotygodniowy pieniędzy, tak przychodu jak rozchodu na zakupienie effektów magazynowych Towarzystwa... 28 IV-4 VI 1839” i „Raport sześciotygodniowy rozchodu effektów magazynowych Towarzystwa... od 20 kwietnia do 1 czerwca 1839 r.” K. 63 wklejony „Raport czterotygodniowy z biletów obiadowych od 1 czerwca do 29 tm. 1839 r.” i „Raport czterotygodniowy z pieniędzy, tak przychodu jak rozchodu na zakupienie effektów do magazynu Towarzystwa... 29 VI 1839 r.” i „Raport czterotygodniowy rozchodu effektów magazynowych 
Towarzystwa... 29 VI 1839”. K. 98 luźna kartka „Stan kasy Towarzystwa... w dniu 7 czerwca 1839 r.” K. 113 luźne kartki: Kwity złożone przez Pana Błotnickiego na sesji Dobroczynności Dam 28 września 1839 r.: Kosicki 35 fr., Malczewski 30 fr. Szczurkiewicz 10 fr., Trzeciak 10 fr., Gajurski 20 fr., Niemirycz 25 fr., Malicki 12 fr., Skarzyński 10 fr., Dobrowolski 20 fr. K. 120 wklejony „Stan kasy Towarzystwa... w d. 15 października 1839 r.” K. 122 wklejony „Stan kasy Towarzystwa... w d. 26 października 1839 r.” K. 130 wklejony „Stan kasy Towarzystwa... z d. 9 listopada 1839 r.” K. 139 wklejony „Stan kasy Towarzystwa... z d. 23 listopada 1839 r.” K. 140 wklejone: „Raport ośmiotygodniowy z biletów obiadowych od 28 IX do 23 XI 1839 r.” i „Raport ośmiotygodniowy, tak przychodu jak rozchodu na zakupienie effektów do magazynu Towarzystwa... 23 XI 1839 r.” i „Raport ośmiotygodniowy rozchodu effektów magazynowych Towarzystwa... od 28 IX do 23 XI 1839 r." K. 145 wklejony „Stan kasy Towarzystwa... w d. 7 grudnia 1839 r.” K. 154 wklejone „Liste des Dames Patronesses qui seront Marchandes à la vente au profit des Refugiés Polonais" (na liście 42 nazwiska). [List otwarty Czartoryskiej z 15 grudnia 1839 roku informujący o Vencie]. List Czartoryskiej do niewymienionej z imienia osoby by została kawalerem przy jednej z dam w czasie Venty. Załączone: „Ustawy dla kawalerów Bazaru”. K. 161 wklejone: „Raport ośmiotygodniowy z biletów obiadowych od 23 listopada 1839 r. do 18 stycznia 1840 r.” i „Raport ośmiotygodniowy, tak przychodu jak rozchodu z pieniędzy na zakupienie effektów magazynowych Towarzystwa... do 18 I 1840 r.” i „Raport ośmiotygodniowy rozchodu effektów magazynowych Towarzystwa... od 23 listopada do 1839 r. do 18 stycznia 1840 r." K. 172 wklejony „Stan kasy Towarzystwa... w d. 14 lutego 1849 r.” K. 184 wklejony „Stan kasy Towarzystwa... w d. 12 marca 1840 r.” K. 185 wklejone „Raport ośmiotygodniowy z biletów obiadowych od 18 I do 13 III 1840 r." i „Raport ośmiotygodniowy, tak przychodu jak rozchodu z pieniędzy na zakupienie effektów do magazynu Towarzystwa... 7 XII 1839-13 III 1840 r.” i „Raport ośmiotygodniowy rozchodu effektów magazynowych Towarzystwa... od 18 I do 13 III 1840 r.”

7. Pol. fran. XIX w. księga 29,5×19 k. 189, opr. płpłt. Protokół Towarzystwa Dobroczynności Dam Polskich w Paryżu 1840, 1841 (od 14 marca 1840 do 6 marca 1841). Posiedzenie 162-181.

Między innymi: „Lista dzieci pobierających wsparcie kwartalne od Towarzystwa Dobroczynności Dam Polskich w Paryżu w roku 1840" (100 nazwisk - pobierają wsparcie od 1836 r.). K 11 wklejone: pismo W. H. Nakwaskiego, członka Towarzystwa Dobroczynności Dam Polskich w Szwajcarii z rozliczeniami za lata 1839 i 1840 oraz wklejony list do księżnej Wirtemberskiej z podziękowaniem Towarzystwa... za odebrane z Wiednia dwóch darów - jeden na 3041 fr., drugi na 1202, 53 fr. K. 20 wklejone: Wykaz sprzedanych fantów na sumę 16.333, 75 fr, sporządzony przez A. Wołowicza z 24 IV 1840 r. i „Stan kasy Towarzystwa... w d. 24 kwietnia 1840 r.” K. 21 Pismo „Prefecture de Police” do księżnej Czartoryskiej z 23 stycznia 1840 r. i drugie z 25 stycznia 1840 r. K. 22 Pismo z 26 lutego 1840 r. „Théatre de la Remaissance” informuje o wystawianej sztuce „La Duchesse de 
Guise”. Bronera - „Proloque en vers de la représentation au bénéfice des Polonais” par M. de Saint-Georges. Paris 1849. K. 23 „,Représentation au bénéfice des Polonais indigens au Théatre de la Renaissance la Vendredi 3 avril 1840 La Duchesse de Guise”. K. 27 wklejony ,Wydatek pocztowy kwartału 2-go od 15 lutego do 26 kwietnia 1840 r.’ K. 31 wklejony list Marylskiego *** w sprawie sprzedaży 500 egzemplarzy dzieła pt. „Pomysły do dziejów Polski”. K. 37 wklejone: „Raport dwumiesięczny z biletów obiadowych od 13 III do 8 V 1840 r.”, „Raport dwumiesięczny, tak przychodu jak rozchodu z pieniędzy na zakupienie effektów do magazynu Towarzystwa... 18 I-8 V 1840 r.”, „Raport dwumiesięczny rozdziału effektów magazynowych Towarzystwa... od 13 III do 8 V 1849 r.”, „Obrachunek magazynu po dzień 13 maja 1840 r.” K. 38 wklejona informacja „Wpływ do kasy d. 22 maja” [1840]. K. 49 wklejony list (projekt do odpowiedzi X.C. do Marylskiego w sprawie „Pomysłu do dziejów Polski”. K. 59 wklejony „Stan kasy Towarzystwa... w d. 5 czerwca 1840 r.”, „Raport miesięczny z biletów obiadowych od 10 maja do 5 czerwca 1840 r.”, „Raport miesięczny, tak przychodu jak rozchodu z pieniędzy na zakupienie effektów magazynowych Towarzystwa... 8 V-5 VI 1840”, „Raport miesięczny rozchodu effektów magazynowych Towarzystwa... od 18 V do 5 VI 1840 r.” K. 61 wklejone, dystrybutor Błotnicki składa następujące kwity: z sesji 24 kwietnia, 28 kwietnia, 8 maja i 22 maja 1840 r. K. 70 wklejony „Stan kasy Towarzystwa... w d. 19 czerwca 1840 r.” K. 78 wklejony „Stan kasy Towarzystwa... z d. 3 lipca 1840 r.” K. 80 wklejony „Raport czterotygodniowy z biletów obiadowych od 5 maja do 3 lipca 1840 r.”, ,Raport czterotygodniowy, tak przychodu jak rozchodu z pieniędzy na zakupienie effektów do magazynu Towarzystwa... 19 VI-3 VII 1840 r.”, „Raport czterotygodniowy rozchodu effektów magazynowych Towarzystwa... od 5 VI do 3 VII 1840 r.” K. 93 wklejony „Stan kasy Towarzystwa... z lipca 1840 r.” K. 108 wklejony „Stan kasy Towarzystwa.. w d. 7 sierpnia 1840 r.” K. 110 wklejone „Raport pięciotygodniowy z biletów obiadowych od 3 VII do 7 VIII 1840 r.”, ,Raport pięciotygodniowy, tak przychodu jak rozchodu z pieniędzy na zakupienie effektów do magazynu Towarzystwa...” [7 VII 1840], „Raport pięciotygodniowy rozchodu effektów magazynowych Towarzystwa... 3 VII-7 VIII 1840 r.” K. 128 wklejony „Stan kasy Towarzystwa... w d. 4 września 1840 r.” K. 129 wklejone: „Raport miesięczny z biletów obiadowych d 7 VIII do 4 IX 1840 r.”, ,Raport miesięczny, tak przychodu jak rozchodu z pieniędzy na zakupienie effektów magazynu Towarzystwa... 7 VIII-4 IX 1840 r.”, ,Raport miesięczny rozchodu effektów magazynowych Towarzystwa... 7 VIII-4 IX 1840 r.” K. 138 wklejony „Stan kasy Towarzystwa... w d. 18 IX 1840 r.” K. 146 wklejony „Stan kasy Towarzystwa... w d. 2 października 1840 r.” K. 148 wklejone: „Raport czterotygodniowy z biletów obiadowych od 4 IX do 2 X 1840 r.”, „Raport czterotygodniowy, tak przychodu jak rozchodu z pieniędzy na zakupienie effektów do magazynu Towarzystwa... 4 IX-2 X 1840 r.”, „Raport czterotygodniowy rozchodu effektów magazynowych Towarzystwa... 4 IX-2 X 1840 r.” Dystrybutor Orłowski składa kwity. K. 165 wklejone: „Raport czterotygodniowy z biletów obiadowych 2 X- 30 X 1840 r.”, ,,Raport czterotygodniowy, tak przychodu jak rozchodu 
pieniędzy na zakupienie effektów do magazynu Towarzystwa...” [3 X 1840], „Raport czterotygodniowy rozchodu effektów magazynowych Towarzystwa 2 X-30 X 1840 r.” K. 165 wklejone kwity złożone przez dra Błotnickiego na sesji d. 30[X] 1840 r. K. 171 wklejony „Stan kasy Towarzystwa... w d. 13 listopada 1840 r.” K. 180 wklejony „Stan kasy Towarzystwa... w d. 27 listopada 1840 r.” K. 181 wklejone: „Raport czterotygodniowy z biletów obiadowych od 30 X do 27 XI 1840 r.”, „Raport czterotygodniowy, tak przychodu jak rozchodu z pieniędzy na zakupienie effektów do magazynu Towarzystwa... 2 X-27 XI 1840 r.”, „Raport czterotygodniowy rozchodu effektów magazynowych Towarzystwa... od 30 X do 27 XI 1840 r.” K. 188 wklejony „Stan kasy dystrybutora Błotnickiego o złożeniu kwitów z dawnych sesji”. 8. Pol. XIX w. księga $30 \times 20$ opr. płótn. k. 172 nie paginowanych i nie zapisanych 67 .

Protokół Towarzystwa Dobroczynności Dam Polskich w Paryżu 1841, 1842 (od 20 marca 1841 do 12 marca 1842). Posiedzenia 187-210.

9. Pol. XIX w. księga 29×20, opr. płt. k. 132.

Protokół Towarzystwa Dobroczynności Dam Polskich w Paryżu 1842, 1843 (od 9 kwietnia 1842 do 11 marca 1843). Posiedzenia 211-228.

10. Pol. XIX w. księga 31×21, opr. płt. k. 127.

Protokół Towarzystwa Dobroczynności Dam Polskich w Paryżu 1843, 1844 (od 1 kwietnia 1843 do [?] 1844). Posiedzenia 229-240.

11. Pol. XIX w. księga $35,5 \times 23$, opr. płt. s. 280 .

Protokół Towarzystwa Dobroczynności Dam Polskich w Paryżu 1844, 1845 (od 16 marca 1844 do 8 marca 1845). Posiedzenia 241-254.

12. Pol. XIX w. księga $30 \times 21$, opr. płt. s. 422 (nie zapisane 419-422).

Protokół posiedzeń Towarzystwa Dobroczynności Dam Polskich w Paryżu 1842, 1845 Posiedzenia 241-252.

13. Brak księgi protokółów nr 13 według numeracji kancelaryjnej. Protokóły posiedzeń 253-263 - brak.

14. Pol. XIX w. księga $31,5 \times 21$, opr. płt. s. 586 .

Protokół posiedzeń Towarzystwa Dobroczynności Dam Polskich w Paryżu 1847, 1848. Posiedzenia 264-275.

15. Pol. XIX w. księga $32 \times 21$, opr. płt. s. 684, nie zapisanych 678-684.

Protokół posiedzeń Towarzystwa Dobroczynności Dam Polskich w Paryżu 1848, 1849 , t. I. Posiedzenia 276-287.

16. Pol. XIX w. księga $29,5 \times 19,6$, str. 250 nie zapisanych $248-250$.

Kontynuacja protokołu posiedzeń Towarzystwa Dobroczynności Dam Polskich w Paryżu 1848, 1849, t. II. Posiedzenia 288-291.

16. Pol. XIX w. księga $31 \times 22$, s. 474, opr. płpł.

Protokół posiedzeń Towarzystwa Dobroczynności Dam Polskich w Paryżu 1849, 1850. Posiedzenia 292-302.

17. Pol. fran. XIX w. księga $31,5 \times 21,5$ opr. płt. s. 432.

Protokół posiedzeń Towarzystwa Dobroczynności Dam Polskich w Paryżu 1850-1851. Posiedzenia 303-313. 
18. Pol. XIX w. księga 30,5×21,5, opr. płt. s. 380 .

Protokół posiedzeń Towarzystwa Dobroczynności Dam Polskich w Paryżu 18511852. Posiedzenia 314-322.

19. Pol. XIX w. księga 31,5×21,5, opr. płt. s. 380, nie zapisanych 292-340 i 378-380.

Protokół posiedzeń Towarzystwa Dobroczynności Dam Polskich w Paryżu 1852 i 1853. Posiedzenia 323-330.

20. Pol. XIX w. księga $31 \times 21,5$, opr. płt. s. 428, strony 429-579 skorowidza nie zapisane.

Protokół posiedzeń Towarzystwa Dobroczynności Dam Polskich w Paryżu 1853. Posiedzenia 331-340.

21. Pol. XIX w. księga $31 \times 21$, opr. płt. s. 588 .

Protokół posiedzeń Towarzystwa Dobro[czynności] Dam Pol[skich] 1854, 1855. Posiedzenia 341-354.

22. Pol. XIX w. księga 31×21, opr. płt. s. 440 .

Dalszy ciąg protokółu posiedzeń Towarzystwa Dobro[czynności] Dam Polskich z roku 1856. Posiedzenia 365-371 (brak protokółów 355-364).

23. Pol. XIX w. księga 31×20, opr. płt. s. 594, nie zapisane 487-594.

Protokół posiedzeń Towarzystwa Dobroczynności Dam Polskich 1858, 1859. Posiedzenia 372-380.

24. Pol. XIX w. księga 34,5×23, opr. płt. s. 476, nie zapisanych 259 st.

Protokół posiedzeń Towarzystwa Dobroczynności Dam Polskich od stycznia 1865 do 22 marca 1901. Posiedzenie 1-177 numerowane, 7 nie numerowanych z lat 8 VI 1904 do 15 I 1906.

25. Pol. XIX w. księga 38×12,5 nie fol., kwity nr 1-594.

Kwitariusz asygnowanych pieniędzy przez Towarzystwo Dobroczynności Dam Polskich w Paryżu od 22 marca 1834 do 12 września 1835 r.

26. Pol. XIX w. księga $45 \times 14$ nie fol.

Kwitariusz asygnowanych pieniędzy przez Towarzystwo Dobroczynności Dam Polskich w Paryżu od 12 września 1835 do 12 listopada 1836 r. (nr kwitów 595-985). 27. Pol. XIX w. księga $42 \times 15$ nie fol.

Kwitariusz asygnowanych pieniędzy przez Towarzystwo Dobroczynności Dam Polskich w Paryżu od 12 listopada 1836 do 6 kwietnia 1839 r. (nr kwitów 986-1771, nie skasowane 986-1035).

28. Pol. XIX w. księga $42 \times 14$ nie fol.

Kwitariusz asygnowanych pieniędzy przez Towarzystwo Dobroczynności Dam Polskich w Paryżu od kwietnia 1839 do 22 lutego 1841 r.

29. Pol. XIX w. księga $44 \times 14$ nie fol.

Kwitariusz asygnowanych pieniędzy przez Towarzystwo Dobroczynności Dam Polskich w Paryżu od 22 lutego 1841 do 12 lutego 1842 r.

30. Pol. XIX w. księga $44 \times 14$ nie fol.

Kwitariusz asygnowanych pieniędzy przez Towarzystwo Dobroczynności Dam Polskich w Paryżu od 12 lutego 1835 do 12 listopada 1842 r. (nr kwitów 828-1656). 
31. Pol. XIX w. księga $44 \times 14$ nie fol.

Kwitariusz asygnowanych pieniędzy przez Towarzystwo Dobroczynności Dam Polskich w Paryżu od 12 listopada 1842 do 4 sierpnia 1843 r. (nr kwitów 1657-2068). 32. Pol. XIX w. księga $44 \times 15$ nie fol., opr. płpłt.

Kwitariusz asygnowanych pieniędzy przez Towarzystwo Dobroczynności Dam Polskich w Paryżu od 5 sierpnia 1844 do 3 sierpnia 1844 r. (nr kwitów 378 z 5 sierpnia 1843 do 1000 z d. 10 lutego 1844 i od nr 1 z d. 2 marca 1844 do 856 z d. 3 sierpnia 1844. Kwit 857 bez nazwiska - przekreślony).

33. Pol. XIX w. księga $44 \times 15$ nie fol., opr. płpłt.

Kwitariusz asygnowanych pieniędzy przez Towarzystwo Dobroczynności Dam Polskich w Paryżu 1844, 1845, od 3 sierpnia 1844 do 3 sierpnia 1844 r. do 5 lipca 1845 (numery kwitów: 857 z d. 3 sierpnia 1844 do 1904 z d. 8 marca 1845 i z d. 5 kwietnia 1845 do 421 z d. 5 lipca 1845).

34. Pol. XIX w. księga $44 \times 15$ nie fol., opr. płpłt.

Kwitariusz asygnowanych pieniędzy przez Towarzystwo Dobroczynności Dam Polskich w Paryżu 1845, 1846 od 5 lipca 1845 do 4 kwietnia 1846 r. (numery kwitów 422 z d. 5 lipca 1845 do 1000 z d. 3 listopada 1845, 1 z d. 3 listopada 1845 do 879 z d. 4 kwietnia 1846).

35. Pol. XIX w. księga $44 \times 15$ nie fol., opr. płpłt.

Kwitariusz asygnowanych pieniędzy przez Towarzystwo Dobroczynności Dam Polskich w Paryżu 1846 od 4 kwietnia do 5 grudnia 1846 r. (numery kwitów: od 880 z d. 4 kwietnia 1846 do 1000 z d. 7 listopada 1846 i od 1 z d. 7 listopada 1846 do 324 z d. 5 grudnia 1846).

Brak trzech kolejnych kwitariuszy 42-44 z lat 1846 do 1849 (kwity od 5 grudnia 1846 do 10 września 1849).

36. Pol. XIX w. księga $44 \times 15$ nie fol., opr. płpłt.

[Kwitariusz asygnowanych pieniędzy przez Towarzystwo Dobroczynności Dam Polskich w Paryżu]. Numery kwitów 466 z d. 10 września 1849 do 2000 z d. 23 lutego 1850 i od 1 z d. 23 lutego 1850 do 940 z d. 10 sierpnia 1850.

37. Pol. XIX w. księga $44 \times 15$ nie fol., opr. płpłt.

[Kwitariusz asygnowanych pieniędzy przez Towarzystwo Dobroczynności Dam Polskich w Paryżu]. Numery kwitów: 941 z 10 sierpnia 1850 do 1000 z d. 8 lutego 1851 oraz 1 z d. 8 lutego 1851 do 695 z d. 7 czerwca 1851.

38. Pol. XIX w. księga $44 \times 16$ nie fol., opr. płpłt.

[Księga asygnowanych pieniędzy przez Towarzystwo Dobroczynności Dam Polskich w Paryżu]. Numery kwitów: 696 z d. 7 czerwca 1851 do 1000 z d. 9 sierpnia $1851 \mathrm{nr} 1 \mathrm{z}$ d. 9 sierpnia 1851 do $1000 \mathrm{z}$ d. 7 lutego 1852 i nr 1 z d. 7 lutego 1852 do $55 \mathrm{z}$ d. 7 lutego 1852.

39. Pol. XIX w. księga $44 \times 16$ nie fol., opr. płpłt.

[Kwitariusz asygnowanych pieniędzy przez Towarzystwo Dobroczynności Dam Polskich w Paryżu]. Numery kwitów 56 z d. 7 lutego 1852 do 1000 z d. 11 września 1852 i nr 1 z d. 11 września 1852 do 420 z d. 23 października 1852. 
40. Pol. XIX w. księga $43 \times 15$ nie fol., opr. płpłt.

[Kwitariusz asygnowanych pieniędzy przez Towarzystwo Dobroczynności Dam Polskich w Paryżu]. Numery kwitów: 421 z d. 23 października 1852 do 1000 z d. 12 marca 1853 i nr 1 z d. 12 marca 1853 do 940 z d. 9 lipca 1853.

41. Pol. XIX w. księga $43 \times 15$ nie fol., opr. płpłt.

[Kwitariusz asygnowanych pieniędzy przez Towarzystwo Dobroczynności Dam Polskich w Paryżu]. Numery kwitów: 941 z d. 9 lipca 1853 do 1000 z d. 15 października 1853 i nr 1 z d. 15 października 1853 do 1000 z d. 14 stycznia 1854 oraz nr 1 z d. 14 stycznia 1854 do 455 z d. 11 marca 1854.

42. Pol. XIX w. księga 44×16 nie fol., opr. płpłt.

[Księga asygnowanych pieniędzy przez Towarzystwo Dobroczynności Dam Polskich w Paryżu]. Numery kwitów: 456 z d. 11 marca 1854 do 1000 z d. 6 maja 1854 i nr 1 z d. 6 maja 1854 do 195 z d. 6 maja 1854.

43. Pol. XIX w. księga $44 \times 15$ nie fol., opr. płpłt.

[Księga asygnowanych pieniędzy przez Towarzystwo Dobroczynności Dam Polskich w Paryżu]. Numery kwitów: 196 z d. 6 maja 1854 do 960 z 10 września 1854. 44. Pol. XIX w. księga 44×16 nie fol., opr. płpłt.

[Księga asygnowanych pieniędzy przez Towarzystwo Dobroczynności Dam Polskich w Paryżu]. Numery kwitów: 961 z d. 10 września 1854 do 1000 z d. 10 września 1854, nr 1 z d. 10 września 1854 do 1000 z d. 17 marca 1855 do 490 z d. 2 czerwca 1855.

45. Pol. XIX w. księga 44×16 nie fol., opr. płpłt.

[Księga asygnowanych pieniędzy przez Towarzystwo Dobroczynności Dam Polskich w Paryżu]. Numery kwitów: 491 z d. 2 czerwca 1855 do 1000 z d. 22 września 1855, nr 1 z d. 22 września 1855 do 1000 z d. 19 kwietnia 1856.

Brak kwitariuszy od numeru 55 do numeru 64. Ostatni kwit nr 1000 jest z d. 19 kwietnia $1856 \mathrm{r}$.

46. Pol. XIX w. księga 49×16 nie fol., opr. płpłt.

[Księga asygnowanych pieniędzy przez Towarzystwo Dobroczynności Dam Polskich w Paryżu]. Numery kwitów: 1 z d. 9 stycznia 1865 do 780 z d. 18 grudnia 1865, nr 1 z d. 5 stycznia 1866 do 780 z d. 6 listopada 1866. Kwity od nr 756 do 780 wypełnione i nie wypłacone, przekreślone.

47. Pol. XIX w. księga $42 \times 16$ nie fol., opr. płpłt.

[Księga asygnowanych pieniędzy przez Towarzystwo Dobroczynności Dam Polskich w Paryżu]. Numery kwitów: 755 z d. 2 listopada 1866 do 994 z d. 31 grudnia 1866, nr 1 z d. 3 stycznia 1867 do 1110 z d. 30 grudnia 1867, nr 1 z d. 2 stycznia 1868 do 555 z d. 30 czerwca 1868.

48. Pol. XIX w. księga 41×14 nie fol., opr. płpłt.

[Księga asygnowanych pieniędzy przez Towarzystwo Dobroczynności Dam Polskich w Paryżu]. Numery kwitów: 556 z d. 1 lipca 1868 do 1041 z d. 30 grudnia 1868 - kwity 1042-1050 skreślone, nr 1 z d. 2 stycznia 1868 do 1030 z d. 31 grudnia 1869, nr 1 z d. 3 stycznia 1870 do 440 z d. 10 maja 1870. 
49. Pol. XIX w. księga $44 \times 16$ nie fol., opr. płpłt.

[Księga asygnowanych pieniędzy przez Towarzystwo Dobroczynności Dam Polskich w Paryżu]. Numery kwitów: 441 z d. 10 maja 1870 do 1140 z d. 31 grudnia 1870, nr 1 z d. 2 stycznia 1871 do 995 z d. 31 grudnia 1871, nr 1 z d. 1 stycznia 1872 do 793 z d. 31 października 1872.

50. Pol. XIX w. księga $44 \times 16$ nie fol., opr. płpłt.

[Księga asygnowanych pieniędzy przez Towarzystwo Dobroczynności Dam Polskich w Paryżu]. Numery kwitów: 796 z d. 1 listopada 1872 do 950 z d. 31 grudnia 1872 , nr 1 z d. 1 stycznia 1873 do 1930 z d. 31 grudnia 1874, nr 1 z d. 1 stycznia 1875 do 403 z d. 11 maja 1875.

51. Pol. XIX w. księga $49 \times 17$ nie fol., opr. płpłt.

[Księga asygnowanych pieniędzy przez Towarzystwo Dobroczynności Dam Polskich w Paryżu]. Numery kwitów: 406 z d. 11 maja 1875 do 997 z d. 31 grudnia 1875, nr 1 z d. 1 stycznia 1876 do 927 z d. 30 listopada 1876.

52. Pol. XIX w. księga $48 \times 17$ nie fol., opr. płpłt.

[Księga asygnowanych pieniędzy przez Towarzystwo Dobroczynności Dam Polskich w Paryżu]. Numery kwitów: 928 z d. 3 listopada 1876 do 997 z d. 31 grudnia 1876, nr 1 z d. 2 stycznia 1877 do 970 z d. 31 grudnia 1877, nr 1 z d. 1 stycznia 1878 do 550 z d. 9 lipca 1878.

Brak kwitariuszy od numeru kancelaryjnego 72 do numeru 98. Pierwszy kwit w kwitariuszu 98 ma numer 302 z d. ... lipca 1906.

53. Pol. XX w. księga $41 \times 17$ nie fol., nie opr.

[Księga asygnowanych pieniędzy przez Towarzystwo Dobroczynności Dam Polskich w Paryżu]. Numery kwitów: 302 z d. ... lipca 1906 do 1397 z d. 1 lutego 1908. 54. Pol. XX w. księga $44 \times 28$ nie fol., opr. płpłt.

[Księga asygnowanych pieniędzy przez Towarzystwo Dobroczynności Dam Polskich w Paryżu]. Numery kwitów: 166 z d. ... marca 1899 do 833 z d. 31 października 1899, nr 1 z d. 3 stycznia 1900 do 737 z 31 grudnia 1900, nr 1 z d. 3 stycznia 1901 do 690 z d. 31 grudnia 1901, nr 2 z 3 stycznia 1902 do 242 z 3 maja 1902. Kwity 336-342 skasowane nie dostarczone.

55. Pol. XX w. księga 42×29 nie fol., opr. płpłt.

[Księga asygnowanych pieniędzy przez Towarzystwo Dobroczynności Dam Polskich w Paryżu]. Numery kwitów: 336 z d. 3 lipca 1902 do 665 z d. 3 grudnia 1902, nr 1 z d. 3 stycznia 1903 do 594 z 31 grudnia 1903, nr 1 z d. 4 stycznia 1904 do 349 z d. 31 lipca 1904.

56. Pol. XX w. księga $42 \times 29$ nie fol., opr. płpłt.

[Księga asygnowanych pieniędzy przez Towarzystwo Dobroczynności Dam Polskich w Paryżu]. Numery kwitów: 353 z d. 3 sierpnia 1904 do 603 z d. ... października 1904, nr 1 ze stycznia 1905 do 614 z 11 grudnia 1905, nr 1 z d. 3 stycznia 1906 do 305 z lipca 1906.

57. Pol. XX w. księga 42×29 nie fol., opr. płpłt. 
[Księga asygnowanych pieniędzy przez Towarzystwo Dobroczynności Dam Polskich w Paryżu]. Numery kwitów: 1403 z d. 12 lutego 1908 do 2514 z d. 2 sierpnia 1909.

58. Pol. XX w. księga $42 \times 29$ nie fol., opr. płpłt.

[Księga asygnowanych pieniędzy przez Towarzystwo Dobroczynności Dam Polskich w Paryżu]. Numery kwitów: 2515 z d. 5 stycznia 1909 do 2500 z d. 17 grudnia 1909.

59. Pol. XX w. księga $42 \times 29$ nie fol., opr. płpłt.

[Księga asygnowanych pieniędzy przez Towarzystwo Dobroczynności Dam Polskich w Paryżu]. Numery kwitów: 2801 z d. 3 stycznia 1910 do 3789 z d. 5 lipca 1911. 60. Pol. XX w. księga $42 \times 29$ nie fol., opr. płpłt.

[Księga asygnowanych pieniędzy przez Towarzystwo Dobroczynności Dam Polskich w Paryżu]. Numery kwitów: 3790 z d. 7 lipca 1911 do 4830 z d. 1 lutego 1913. 61. Pol. XX w. księga $42 \times 29$ nie fol., opr. płpłt.

[Księga asygnowanych pieniędzy przez Towarzystwo Dobroczynności Dam Polskich w Paryżu]. Numery kwitów: 4831 z d. 1 lutego 1919 do 5814 z 4 września 1914. 62. Pol. XX w. księga $42 \times 29$ nie fol., opr. płpłt.

[Księga asygnowanych pieniędzy przez Towarzystwo Dobroczynności Dam Polskich w Paryżu]. Numery kwitów: 5815 z d. 3 września 1914 do 6828 z d. 1 czerwca 1916.

63. Pol. XX w. księga $42 \times 29$ nie fol., opr. płpłt.

[Księga asygnowanych pieniędzy przez Towarzystwo Dobroczynności Dam Polskich w Paryżu]. Numery kwitów: 6829 z d. 1 czerwca 1916 do 7752 z d. 5 czerwca 1918.

64. Pol. XX w. księga $42 \times 29$ nie fol., opr. płpłt.

[Księga asygnowanych pieniędzy przez Towarzystwo Dobroczynności Dam Polskich w Paryżu]. Numery kwitów: 7753 z d. 1 marca 1918 do 10021 z d. 31 lipca 1922. 